\title{
Ovipositing behavior in the egg-brooding frog Stefania ayangannae (Anura, Hemiphractidae)
}

\author{
D. Bruce Means ${ }^{1}$, William E. Duellman ${ }^{2}$ and Valerie C. Clark ${ }^{3}$ \\ ${ }^{1}$ Coastal Plains Institute and Land Conservancy, 1313 Milton Street, Tallahassee, FL 32303, USA. \\ E-mail: means@bio.fsu.edu. \\ 2 Natural History Museum and Biodiversity Research Center, University of Kansas, 1345 Jayhawk Blvd., Lawrence, Kansas \\ 66045, USA. E-mail: duellman@ku.edu. \\ 3 School of Pharmacy, Queen's University in Belfast, Belfast BT9 7BL, Northern Ireland, UK. \\ E-mail: frogchemistry@gmail.com.
}

Keywords: Anura, Hemiphractidae, Stefania ayangannae, ovipositing behavior, Wokomung Massif, Guyana.

Palabras clave: Anura, Hemiphractidae, Stefania ayangannae, comportamiento de la postura, Wokomung Massif, Guyana.

Frogs of the family Hemiphractidae, as recognized by Wiens et al. (2007), are unique among anurans in that the eggs develop on the back or in dorsal pouches in the female (Duellman and Maness 1980). Females of species of Cryptobatrachus, Hemiphractus, and Stefania carry their eggs and young on their backs; the eggs are attached to the body by a glutinous material (Jungfer and Boehme 1991). In other hemiphractids, the eggs develop in a closed pouch (Gastrotheca and some Flectonotus) or in an open pouch (other Flectonotus).

All of the growing list of species of Stefania (MacCulloch and Lathrop 2002) are known only from the slopes, summits, and surrounding lowlands of tepuis of the Guayana Highlands in Venezuela, Brazil, and Guyana (McDiarmid and Donnelly 2005). Eggs and/or young carried on the back of female Stefania have been reported

Received 2 October 2008.

Accepted 9 December 2008.

Distributed December 2008. for at least 6 of the 18 described species (Rivero 1968, Duellman and Hoogmoed 1984, Señaris et al. 1997, MacCulloch and Lathrop 2006a,b,c). Oviposition, male behavior during fertilization, and placement of eggs on the female's dorsum have been described in one captive pair of Stefania (species not identified but probably $S$. riveroi) from Yuruani tepui in Venezeula (Magdefrau 1991). Herein we describe these behaviors in a wild pair of $S$. ayangannae from the summit of a tepui in Guyana.

At 20:45 h on 16 July 2007 one of us (DBM) discovered and photographed an amplectant pair of Stefania ayangannae on the strap leaf of a bromeliad at 1524 m elevation on Mt. Kopinang, the southwest part of the larger Wokomung Massif, 0500'08' N, 5952'47” W, Potaro-Siparuni District, Guyana. Amplexus was axillary, but it was not entirely evident where the male's hands rested. Later examination of photographs revealed that at least one finger rested over the upper arm of the 
female. No eggs were visible under the smaller male (35.8 mm SVL; female $48.4 \mathrm{~mm} \mathrm{SVL}$ ); the frogs were left alone for 21 minutes. At 21:09 $\mathrm{h}$ the white color of at least one egg was visible under the male. DBM then observed and photographed (35 mm Nikon D200 camera) oviposition behavior until 22:00 h. During that time, six ovipositions were observed about two minutes apart (at 21:11, 21:13, 21:15, 21:17, $21: 21,21: 23 \mathrm{~h}$ ) as well as two false ovipositions (21:25, 21:28 h).

A typical oviposition event began when the female elevated her rump slightly and a large, white ovum was extruded (Figure 1A). The female's cloacal opening was located at the top of her rump so that after the ovum was extruded, it rolled downhill on the female's back toward the male (Figure 1B). The male used both hind feet to arrange the large eggs under his venter and on the female's dorsum by reaching out laterally and posteriorly, pulling the new ovum beneath him, and then sweeping his feet gently under his belly and positioning all the eggs in one plane on the female's dorsum (Figure 1C). The male's sperm is suspected to have been deposited among the eggs but no effluvium was observed coming from the male's cloaca. The male was relatively inactive until the female initiated oviposition movements. He did not seem to stimulate any of the female's behavior. However, the use of his back legs and feet were stimulated by the slight movements of the female during extrusion of an ovum.

At $21: 25 \mathrm{~h}$ the female raised her rump slightly and opened her cloaca revealing red and white tissue of the cloacal lining, but no ovum was extruded (Figure 1D). This was assumed to be a false oviposition because the movements were identical to earlier events. The male shuffled the eggs a little with the characteristic sweeping motion of his feet. The eggs were observed to move freely under the male while he was shuffling them around with his feet.

At 21:48 h a novel event occurred that was not photographed because the camera lens was jammed. As the male elevated his rump exposing the eggs, a small, club-shaped protrusion of skin extended from the top of the female's cloaca anteriorly beneath the male; although this was not photographed, it is drawn in Figure 2. Some clear liquid was squirted from the protrusion onto the eggs; this possibly becomes the glutinous material that fastens the eggs onto her back. Histological examination of this structure is beyond the realm of this paper and is the subject of a future study. No further reproductive behavior was observed by 22:00 h, so the amplectant pair was collected and kept overnight in an inflated plastic bag. The next morning, the male had released the female, and nine eggs were firmly glued to her dorsum (Figure 3; $\bar{x}$ of 9 smallest dimensions +9 longest dimensions $=6.7 \pm 0.48 \mathrm{~mm}$ diameter, range $=5.5-7.5 \mathrm{~mm}$ ). Both frogs were euthanized in $10 \%$ ethanol and later preserved (CPI-10506-07) in 90\% ethanol.

That same night, another female $(48.5 \mathrm{~mm}$ SVL) was collected within $\sim 50 \mathrm{~m}$ of the first pair with seven apparently freshly laid eggs $(\bar{x}$ of 7 smallest dimensions +7 longest dimensions $=7.4 \pm 0.64 \mathrm{~mm}$ diameter, range $=$ $6.3-8.7 \mathrm{~mm}$ ) glued to her dorsum. July is normally the third month in a four-month-long rainy season, but the weather had been relatively dry until earlier in the day when approximately $2-3 \mathrm{~cm}$ of rain fell. That two pairs of Stefania ayangannae were found to have oviposited early in the evening of 16 July 2007 suggests that the rain triggered the events. Means (personal observation) discovered a female carrying seven eggs on her back with young, gilled embryos on 27 April 2003 on the highest point of the Wokomung Massif $\left(05^{\circ} 04^{\prime} 54.7 " \mathrm{~N}, 59^{\circ} 50^{\prime} 25.5\right.$ " W, $\sim 1524 \mathrm{~m}$ elevation). One female with four advanced eggs and another with four juveniles was reported for this species between 25 October-1 November on Mt. Ayanganna (MacCulloch and Lathrop 2002) and 5-8 juveniles were observed on the backs of seven adult females on the Wokomung Massif in October and November (MacCulloch, 

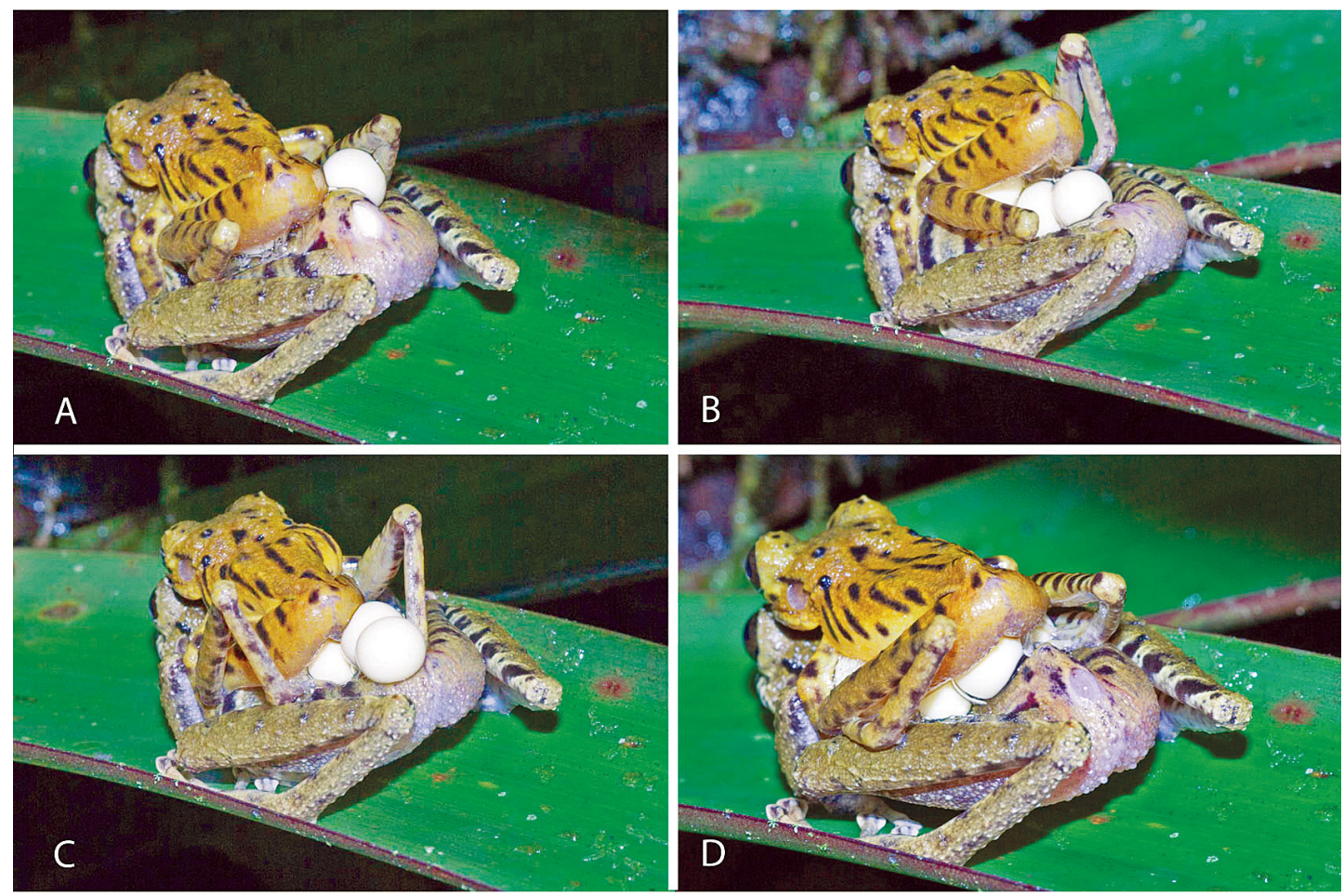

Figure 1 - (A) Stefania ayangannae initiating oviposition with cloaca directed upward and an ovum partially extruded; (B) ovum has rolled forward down female's (CPI 10507) back. and male (CPI 10508) is beginning to sweep ovum under his abdomen with his right foot; (C) male shuffling eggs under his abdomen with both feet simultaneously; (D) female engaged in "false oviposition."

et al. 2006). All specimens were euthanized in $10 \%$ ethanol and fixed in $90 \%$ ethanol to preserve DNA. These data indicate that oviposition in Stefania ayangannae occurs from April to July and advanced embryos and young are found in October and November. Upon dissection, the female was not found to have any additional enlarged ova in her ovaries or oviducts.

Observations on mating and oviposition have been reported for only seven of the more than 80 species of hemiphractid frogs. Detailed photographs of oviposition behavior are available only for Flectonotus goeldii (Weygoldt and Carvalho e Silva, 1991) and Stefania ayangannae. In the latter a protrusible structure from the female's cloaca is visible
(Figure 3). The details of this structure are unknown; it may exist in other hemiphractid frogs but has not been detected in the few observations of oviposition behavior. Magdefrau's (1991) observations of a captive pair of Stefania cf. riveroi from Yuruani Tepui in Venezuela are similar to our observations of wild $S$. ayangannae in several ways - amplexus is axillary, at least one finger of the male is placed over the upper arm of the female, backand-forth wiping motion of the male's feet to arrange the ova beneath him is similar, and the time from initiation to completion of oviposition was about $2 \mathrm{~h}$ in both species. The secretion of seminal fluids was not observed in either pairing, but the fluids may have been clear, of 
small volume, and simply gone undetected in both instances. We were not present prior to oviposition in $S$. ayangannae to observe whether the male wiped his feet across the female's cloaca to create a foamy mass on her back as was observed in $S$. cf. riveroi by Magdefrau (1991).

Data on the mating behavior of captive individuals of Flectonotus goeldii by Weygoldt and Carvalho e Silva (1991), F. pygmaeus by Duellman and Maness (1980) and Duellman and Gray (1983), and $F$. fitgeraldi (series of photographes in Herrmann 2001) reveal basically the same kinds of behavior, which includes the female arching her back and directing the cloaca upward, the male placing his cloaca and feet above the female's cloaca and grasping extruded eggs with his feet and pushing them under his body and onto the back of the female in $F$. goeldii or into the posterior opening of the pouch in $F$. pygmaeus. In $F$. goeldii, dermal ridges elevate to surround the eggs but not enclose them. During the course of oviposition in $F$. goeldii a mucus secretion (probably from the oviducts) appears on her back; the male uses his feet to stir this secretion into a foamy forth, which subsequently surrounds all of the eggs and finally hardens into an ephemeral structure to which the eggs are adhered.

Observations on the mating behavior in captive individuals of Gastrotheca riobambae (as G. marsupiata) by Harrison Matthews (1957), Deckert (1963), and Hoogmoed (1967) reveals that the female elevates the cloacal region to a level equal to, or above, the opening of the dorsal brood pouch. The male produces fluid that presumably contains sperm from the cloaca; he wipes this fluid over the female from her cloaca to the opening of the pouch with his feet. As eggs are extruded by the female, the male directs the eggs into the pouch with his feet. Mertens's (1957) observations of breeding in captive individuals of Gastrotheca ovifera from Rancho Grande, Venezuela, are somewhat different. He noted that during amplexus the female raised the posterior part of her body by

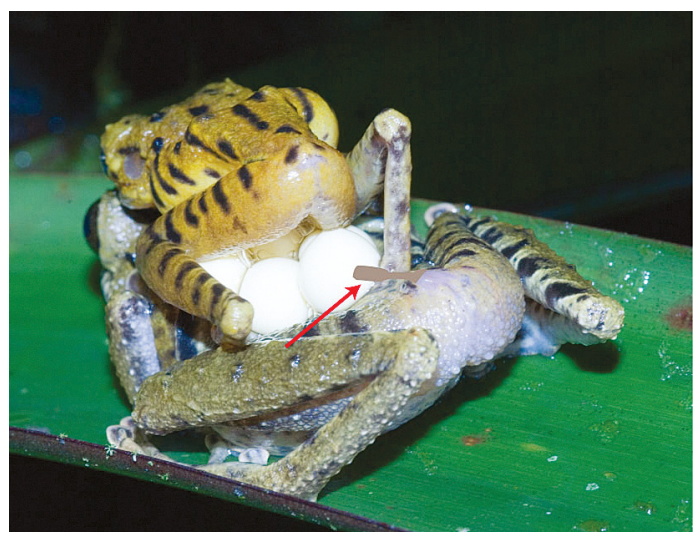

Figure 2 - Female Stefania ayangannae with club-shaped protrusion (shaded brown) on the top of her cloaca directed anteriorly and squirting fluid onto the eggs.

extending the hind limbs; in this position with the amplectant pair tilted head-down, eggs were extruded from the cloaca. The eggs moved by gravity into the pouch unassisted by the male's feet. Presumably the eggs were fertilized as they entered the pouch, because the cloaca of the male was positioned just posterior to the opening of the pouch.

Oviposition behavior is unknown for Cryptobatrachus and Hemiphractus, both of which are like Stefania in brooding eggs openly

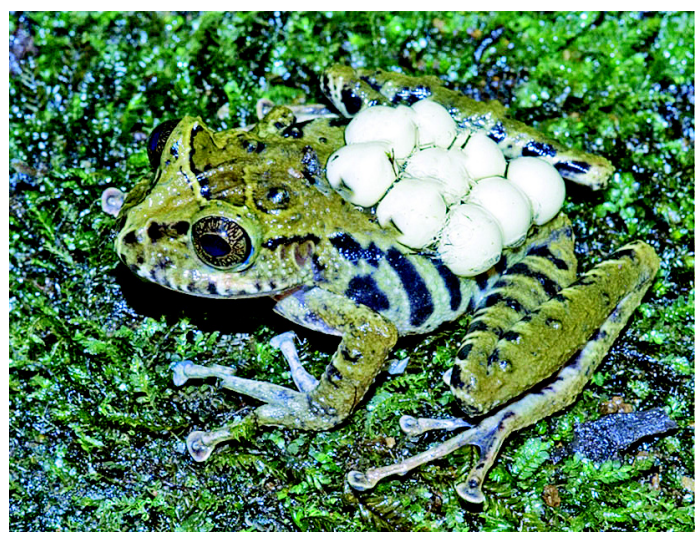

Figure 3 - Female Stefania ayangannae (CPI 10530) with nine eggs on dorsum. 
on the back of the female. Presumably their oviposition behavior is like that of Stefania. Although there are some minor differences in behavior, in all hemiphractid frogs in which oviposition has been observed, males in axillary amplexus play an active role in the placement of eggs either on the back of, or in a pouch in, the female. Thus, male and female reproductive behavior apparently is another unique feature of Hemiphractidae, along with egg brooding and enlarged, bell-shaped, external embryonic gills.

\section{Acknowledgements}

Permission to conduct biodiversity research was granted by the Guyana Environmental Protection Agency under permit \# 120707 BR 075 and permission to export specimens for taxonomic study was granted under EPA permit \# 230707 SP:008. Partial funding for this research was provided by a grant from the National Institutes of Health (\# GM053830-34) to Jerrold Meinwald (Cornell University). We thank staff at the NIH, including Tom Nucci, for approvals. Specimens were euthanised according to approved protocols. We thank Michelle Kalamandeen of the University of Guyana Biodiversity Centre and Philip da Silva of the University of Guyana Biology Department for assisting us with specimen export permits and the following persons of the Guyana Department of Environmental Protection for assisting us with in-country collecting permits: Annie Pitamber, Ramesh Lilwah, Doorga Pursaud, and their colleagues. We thank Phyllis Seargent and the Honorable Carolyn Rodrigues of the Guyana Ministry of Amerindian Affairs for a permit to enter Amerindian lands, and Captain Cecil Johnny and the people of Kopinang Village for housing and multiple courtesies aiding our expedition. We thank the following persons for assistance in the field: Dion Johnny, Gilford Pio, and Reggie Alexander of Kopinang Village and Neil Jafer and Forrest Smartt, students at the University of Guyana.

\section{References}

Deckert, K. 1963. Die Paarung des Beutelfrosches (Gastrotheca marsupiata). Zoologische Garten (NF) 28: 12-17.

Duellman, W. E. and P. Gray. 1983. Developmental biology and systematics of the egg-brooding hylid frogs, genera Flectonotus and Fritziana. Herpetologica 39: $333-359$.

Duellman, W. E. and M. S. Hoogmoed. 1984. The taxonomy and phylogenetic relationships of the hylid frog genus Stefania. University of Kansas Museum of Natural History Miscellaneous Publications 75: 1-39.

Duellman, W. E. and S. J. Maness. 1980. The reproductive behavior of some hylid marsupial frogs. Journal of Herpetology 14: 213-222.

Harrison Matthews, L. 1957. Viviparity in Gastrotheca (Amphibia: Anura) and some considerations on the evolution of viviparity. Bulletin de la Société Zoologique de France 82: 317-320.

Herrmann, H.-J. 2001. Terrarien Atlas, Band 1. Mergus Verlag GmbH., Melle, Germany. 1152 pp.

Hoogmoed, M. S. 1967. Mating and early development of Gastrotheca marsupiata (Duméril and Bibron) in captivity (Hylidae, Anura, Amphibia). British Journal of Herpetology 4: 1-7.

Jungfer, K-H. and W. Boehme. 1991. The backpack strategy of parental care in frogs, with notes on frogletcarrying in Stefania evansi (Boulenger, 1904) (Anura: Hylidae: Hemiphractinae). Revue Francaise d'Aquariologie 18: 91-96.

MacCulloch, R. D. and A. Lathrop. 2002. Exceptional diversity of Stefania (Anura: Hylidae) on Mount Ayanganna, Guyana: three new species and new distribution records. Herpetologica 58: 327-346.

MacCulloch, R. D. and A. Lathrop 2006a. Stefania ayangannae MacCulloch and Lathrop. Catalogue of American Amphibians and Reptiles 825: 1-2.

MacCulloch, R. D. and A, Lathrop 2006b. Stefania coxi MacCulloch and Lathrop. Catalogue of American Amphibians and Reptiles 826: 1-2.

MacCulloch, R. D. and A. Lathrop 2006c. Stefania evansi (Boulenger). Catalogue of American Amphibians and Reptiles 827: 1-3.

MacCulloch, R. D., A. Lathrop and S. Z. Khan. 2006. Exceptional diversity of Stefania (Anura, Cryptobatrachidae) II: Six species from Mount Wokomung, Guyana. Phyllomedusa 5: 31-41.

Magdefrau, H. 1991. Rufe, Paarung und Eiablage bei einer Froschart der Gattung Stefania (Rivero, 1966). Herpetofauna 13: 7-13.

McDiarmid, R. W. and M. A. Donnelly. 2005. The 
herpetology of the Guayana Highlands: Amphibians and reptiles of the Lost World. Pp. 461-560 in M. A. Donnelly, B. I. Crother, C. Guyer, M. H. Wake, and M. E. White (eds.), Ecology and Evolution in the Tropics, a Herpetological Perspective. Chicago. University of Chicago Press.

Mertens, R. 1957. Zur Naturgeschichte des venezolanischen Reisen-Beutelfrosches, Gastrotheca ovifera. Zoologische Garten (NF) 23: 110-133.

Rivero, J. A. "1966” [1968]. Notes on the genus Cryptobratrachus (Amphibia, Salientia) with the description of a new race and four new species of a new genus of hylid frogs. Caribbean Journal of Science 6: 137-149.
Señaris, J. C., J. Ayarzagüena and S. Gorzula. "1996" [1997]. Revisión taxonómica del género Stefania (Anura; Hylidae) en Venezuela con la descripción de cinco nuevas especies. Publicaciones de la Asociación de Amigos de Doñana 7: 1-57.

Weygoldt, P. and S. P. Carvalho e Silva. 1991. Observations on mating, oviposition, egg sac formation, and development in the egg-brooding frog, Fritziana goeldii. Amphibia-Reptilia 12: 67-80.

Wiens, J. J., C. A. Kuczynski, W. E. Duellman, and T. W. Reeder. 2007. Loss and re-evolution of complex life cycles in marsupial frogs: Does ancestral trait reconstruction mislead? Evolution 61: 1886-1899. 